\title{
Fair Value Information, Audit fees and Audit Committee in Taiwan
}

\author{
Shu-Hsing $\mathrm{Wu}^{1}$, Tsung-Che $\mathrm{Wu}^{2} \&$ Kun-Lin Yang ${ }^{3}$ \\ ${ }^{1}$ Associate Professor, Chang Jung Christian University, Taiwan \\ ${ }^{2}$ Assistant Professor, Department of Banking and Finance, National Chiayi University, Taiwan \\ ${ }^{3}$ Graduate School of Business and Operations Management, Chang Jung Christian University, Taiwan \\ Correspondence: Tsung-Che Wu, Assistant Professor, Department of Banking and Finance, National Chiayi \\ University, Taiwan.
}

Received: March 9, 2017

Accepted: March 27, 2017

Online Published: April 8, 2017

doi:10.5430/ijfr.v8n2p124

URL: https://doi.org/10.5430/ijfr.v8n2p124

\begin{abstract}
Regulatory requirements to adopt IFRS and to disclose audit fees make it possible to examine association between audit fees and proportion of fair-valued assets among firms in Taiwan. A voluntary choice of adding audit committee in the firm for monitoring purpose also helps to examine the association further. Empirical results indicate that lower audit fees is related to higher proportion of (Level 2) fair-valued assets, a finding consistent to Goncharov et al.'s (2014) suggestion that firms pay lower audit fees with fair-value model than with cost model. Insignificant association is found for proportion of Level 3 fair-valued assets, which is similar to Glover et al.'s (2014) suggestion that firm's reluctant attitude in adopting Level 3 assets. Last of all, when audit committee is added, firm's audit fees is negatively associated with Level 1 and 2 fair-valued assets, implying audit committee's role of monitoring and further reducing audit risk and audit fees among Taiwanese firms.
\end{abstract}

Keywords: fair value information, audit fees, audit committee

\section{Introduction}

Due to the impact of 1997 Asian financial crisis and a series of corporate financial scandals afterward, domestically and internationally, in early 2000's, regulators in Taiwan started to concern the importance of corporate governance and related financial regulations. For example, in 2002, Securities and Futures Bureau revised the "Regulations Governing the Preparation of Financial Reports by Securities Issuers" and requiring firms to disclose audit fees. Since 2013, Taiwanese firms started to adopt the International Financial Reporting Standards (IFRS) and thus to follow the requirements at IAS 39: "Financial Instruments: Recognition and Measurement" and IFRS 7 "Financial Instruments: Disclosures". Firms are required to measure and disclose fair valued assets and liabilities in three level of inputs. Since 2007, under the requirement of Financial Supervisory Commission, firms in Taiwan may voluntary set audit committee, which includes independent directors only, within corporate board for monitoring purpose rather than adopt the conventional two-tiered supervisor-board.

Prior research indicates that the complexity in estimating fair value of assets, due to the uncertainty of input value and the impact of environmental factors, may increase the complexity of auditing service and thus increase audit fees (Ettredge, Xu, and Yi, 2014). However, Goncharov, Riedl, and Sellhorn (2014) find the audit fees based on fair value model are lower than those based on cost model. Thus, in this study, we first explore the association between audit fees and proportion of fair valued assets among publicly listed firms in Taiwan.

Although adopting fair value model increase disclosure of accounting information, firms instead have more options on the choice of accounting policies. Ettredge, $\mathrm{Xu}$, and Yi (2014) suggest that, comparing to Level 3 assets, the association between audit fees and Level 1 or Level 2 fair valued assets are more significant. In addition, Laux and Leuz (2010) suggest that firms tend to adopt more Level 2 assets. Thus, in this study, we further examine whether firms pay less audit fees if there are higher proportion of Level 2 assets to total assets in the firms.

To enhance corporate governance at publicly listed firms in Taiwan, Financial Supervisory Commission require firms to either set audit committee within the board or maintain conventional two-tier supervisors-board structure. The audit committee consists at least three members, appointed from independent directors and at least one member with accounting or finance profession. In prior research, Kim, Segal, Segal, and Zang (2013) suggest that audit committee 
members may have more understanding on the consequence of management's opportunisms and failed financial reporting (such as share price decrease or bankruptcy). Beasley, Carcello, Hermanson, and Neal (2009) suggest that investors can have more understanding on the firm by analyzing financial reports under audit committee's monitoring. Loukil (2014) suggests that audit committee members, such as independent directors with finance and accounting profession or frequent attendance members, may help accountants to be more confident with firm's accounting quality and to set lower auditing risk. In this study, we further add interaction terms of audit committee and fair valued assets in the model to examine whether appointing audit committee in the firm can enhance the association of fair valued assets on audit fees.

Empirical results indicate that lower audit fees is related to higher proportion of fair valued assets to total assets, a finding consistent to Goncharov, Riedl, and Sellhorn's (2014) suggestion that firms pay lower audit fees with fair value model than with cost model. We also find negative association between audit fees and the proportion of Level 2 fair valued assets. The association is not significant for Level 3 fair valued assets, a result similar to Glover, Taylor, and Wu's (2014) suggestion that firm's reluctant attitude in adopting Level 3 assets due to less reliable information or investor's' suspicion. Last of all, we find that when audit committee is added, firm's audit fees is negatively associated with Level 1 and 2 fair valued assets, implying audit committee's role of monitoring firm's fair valued assets and further reducing audit risk and audit fees. To our understanding, the finding adds to the literature on corporate governance and fair value assets in Taiwan, especially the global convergence of U.S. featured audit committee (Dallas and Scott, 2006; Hsu, 2014) in Taiwanese firms for monitoring purpose.

The remainder of the paper is organized as follows. Section II introduces prior studies on the audit fees and auditing/non-auditing service. In Section III, we describe research design, including research hypotheses, sample selection, and research models. We present results of empirical analysis in Section IV and conclude in Section V.

\section{Literature Review}

\subsection{Audit Fees}

Simunic (1980) suggests that two major factors influencing audit fees are feature of accountants and audited firms. Research variables in Simunic's research include firm size (total assets), debt to asset ratio, industry category, profitability in previous three years, PE ratio, internal auditing cost, service years and scale of accounting firm, auditing opinion. Empirical results indicate that firm scale is the most significant factor for audit fees. Audit fees, as a result of negotiation between accounting firm and firm to be audited, would consist certain potential information and reflect auditing quality and risk.

Research of Simon and Francis (1988) and Whisenant, Sankaraguruswamy, and Raghunandan (2003) suggest that liability is a measurement of auditing risk. Thus higher audit fees is expected for higher risk. However, Gul and Tsui (2001) suggest that when liability ratio increases, more monitoring due to liabilities will alleviate agency problem and decrease loading of auditing works instead. Casey and Grenier (2014) suggest that accountants in accounting firms having long-term business relation with client firms may provide auditing service based on past experience and management manipulation, mainly due to decreased sensitivity and suspicion, and may charge less audit fees. Song, Thomas, and Yi (2010) examine value relevance of FAS No. 157 fair value hierarchy information and find that stock price is significantly related to Level 1 and Level 2 assets but not Level 3 assets.

\subsection{Auditing and Non-auditing Service}

Davis, Ricchiute, and Trompeter (1993) posit that higher audit fees, paid by client firms who also request non-auditing service, is the result of accountant's extra effort. On the other hand, Duh, Lee, Lin and Chu (2007) suggest that if auditing quality is impaired by accountant's incentive and attention on audit fees, restricting accountants to offer non-auditing services may drive those services to go underground and even been manipulated.

Jubb, Houghton, and Butterworth (1996) suggest that higher proportion of non-audit fees, implying higher potential overflow effect or substitution between auditing and non-auditing service, will have impact on audit fee charges. Simunic (1984), Simon (1985) and Palmrose (1986) find positive association between audit fees and non-auditing service. The major reason is the effect of knowledge overflow in auditing service when dealing with non-auditing service. Cahan, Emanuel, Hay and Wong (2008) find significant positive association between non-audit fees time period and client importance. Evidence found on discretionary accruals implied that providing both auditing and non-auditing service to long-term and important client firms may reduce auditor independence.

\subsection{Scale of Accounting Firms}

$\mathrm{Su}$ (2000) adopt Simunic's (1980) research structure to examine the association of audit fees and scale of accounting 
firm in Taiwan. Results indicate that higher audit fees are charged among the top three accounting firms in Taiwan. Simunic (1980) suggests that audit fees is related to firm size (total asset), debt to asset ratio, industry category, profitability in previous years, PE ratio, internal auditing cost, service years and scale of accounting firm, auditing opinion. Sirois and Simunic (2011) suggest the major difference between big four and non-big four accounting firms is the differentiation of auditing techniques. Big four accounting firms increase auditing quality through enhanced examination techniques. Francis and Yu (2009) explore the association between big four accounting firms and audit quality. Results indicate that higher audit quality is the result of more professionals in providing better service and higher opportunity to offer going concern opinion and to reduce clients' earning management conducts.

\section{Research Design}

\subsection{Research Hypotheses}

\subsubsection{Fair Value Assets and Audit Fees}

Results in prior research indicate that the estimation of fair value information is vulnerable to management manipulation (Ramanna and Watts, 2010) and is related to higher auditing risk and audit fees. Goncharov, Riedl, and Sellhorn (2014) suggest that fair value information collected from liquid markets can reduce accountant's reliance on management estimation and audit fees.

Earley, Hoffman and Joe (2014) comparing the audit fees with fair value model and with cost model. They find that firms with fair value model pay less in audit fees. Goncharov, Riedl and Sellhorn (2014) suggest that the effect impairment test with cost model is a reason for higher audit fees. On the other hand, with fair value model, accountants arrange evaluation process only when asset value is lower than market value. Thus, we posit that firms with more fair valued assets, relative to total assets, tend to pay less in audit fees. The first hypothesis is:

\section{H1: Firms' audit fees are negatively related to the proportion of fair value assets.}

\subsubsection{Three Levels of Input in Fair Valued Assets}

Glover, Taylor and $\mathrm{Wu}$ (2014) suggest that the purpose of accountants is to ensure accounting items are correctly classified without specific preference. Considering the strict fair value requirements, accountants tend to classify assets with Level 2 or Level 3 inputs.

Casey and Grenier (2015) suggest that accountants in accounting firms having long-term business relation with client firms may provide auditing service based on past experience and management manipulation, mainly due to decreased sensitivity and suspicion, and may charge less auditing fee. Ettredge, $\mathrm{Xu}$, and Yi (2014) suggest fair value assets based on Level 1 input are more reliable than Level 2 or Level 3 inputs due to the open market data available for Level 1 assets. Goncharov, Riedl, and Sellhorn (2014) suggest adopting fair value model would reduce audit fees, but audit fees may increase with the complexity of fair value evaluation. Results in recent research indicate that firms tend to adopt more Level 2 input in asset classification (Laux and Leuz 2010). Thus in Hypothesis 2, we posit that:

H2: The association between audit fees and Level 2 fair valued assets is stronger than the association between audit fees and Level 1 fair valued assets.

\subsubsection{Interaction of Fair Valued Assets and Audit Committee}

Kim, Segal, Segal, and Zang (2013) suggest that audit committee members may have more understanding on the consequence of management's opportunisms and failed financial reporting (such as share price decrease or bankruptcy). Beasley, Carcello, Hermanson, and Neal (2009) suggest that investors can have more understanding on the firm by analyzing financial reports that is under audit committee's monitoring. Key function of audit committee is to provide fair financial information and to complete internal control system and compliance of legal and ethical behavior among management and employees.

Loukil (2014) suggests that audit committee members, such as independent directors with finance and accounting profession, may help accountants to have more confidence with firm's accounting quality and to set lower level of auditing risk. This proposition implies a substitution effect exists between audit committee and external auditing.

In Taiwan, according to Securities and Exchange Act. 14-4, audit committee members should be appointed from independent directors in the firm. Independent directors, based on Company Act. 192-1, should be nominated by shareholders with at least $1 \%$ shareholdings. We speculate that audit committee members' responsibility is not only monitoring external auditing, but also monitoring a comprehensive auditing process, including cost control on audit fees. Thus, we posit the Hypothesis 3 as:

H3: Audit fees on fair valued assets will be lower for firms set up with audit committee. 


\subsection{Sample Selection}

In this research, we collect sample data from publicly listed firms in Taiwan between 2007 and 2014 to examine our hypotheses. The data of firm's financial statements, Level 1,2 and 3 input of fair valued assets, and audit committee is collected from Taiwan Economic Journal (TEJ) database. The definition of fair value assets is based on IFRS 13 Fair Value Measurement. After deleting the missing data, the sample consists 2,042 observations of publicly listed firms in Taiwan between 2007 and 2014.

\subsection{Research Models}

\subsubsection{Fair Value Assets and Audit Fees}

In Model 1, we apply Ettredge, Xu, and Yi's (2014) model to examine if the proportion of fair valued assets is negatively related to firm's audit fees that. In Model 1, we take natural-log-transformed value of audit fees (LnAFee) as dependent variable and the proportion of fair valued assets (FVA_TA), calculated as fair-valued assets deflated by total assets, as independent variable. Model 1 is as follows:

$\operatorname{LnAFee}_{i, t}=$

$\beta_{0}+\beta_{1}$ FVA $_{-} T A_{i, t}+\beta_{2}$ LnAsset $_{i, t}+\beta_{3}$ Big $_{i, t}+\beta_{4}$ Inv $_{-} T A_{i, t}+\beta_{5} L_{-} T A_{i, t}+\beta_{6}$ Loss $_{i, t}+\beta_{7}$ Efficiency $_{i, t}+$

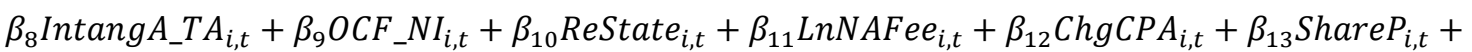

$\beta_{14}$ Opnion $_{i, t}+\beta_{15}$ ROE $_{i, t}+\beta_{16}$ Impair $_{i, t}+\beta_{17}$ AComit $_{i, t}+\beta_{18}$ OCI $_{i, t}+\beta_{19}$ OCInon $_{i, t}+\beta_{20}$ InvestProp $_{i, t}+$

YearDummy + IndDummy

Control variables are as follows.

LnAsset is the natural-log-transformed of total assets; Big4 is a dichotomous variable coded as 1 for firms audited by Big-4 auditors and 0 for non-Big-4 auditors; $\mathbf{I n v} \boldsymbol{T} \boldsymbol{T A}$ is inventory and deflated by total assets; $\boldsymbol{L} \_\boldsymbol{T A}$ is liability and deflated by total assets; Loss is a dichotomous variable coded as 1 for firms with negative net income, 0 otherwise; Efficiency is measured by dividing operating expenses by total revenue; Intang $\boldsymbol{A}_{-} \boldsymbol{T A}$ is intangible assets and deflated by total assets; $\boldsymbol{O C F} \_\boldsymbol{N I}$ is operating cashflows and deflated by net income; ReState is a dichotomous variable coded as 1 for accounting restatement, 0 otherwise; LnNAFee is the natural-log-transformed value of non-audit fees; $\boldsymbol{C n g C P A}$ is a dichotomous variable coded as 1 for firms change accounting firms, 0 otherwise; ShareP is the share price of firm; Opinion is a dichotomous variable coded as 1 for firms with Unqualified opinion in audit report, 0 otherwise; $\boldsymbol{R O E}$ is return on equity; ImpairA is the natural-log-transformed value of impairment of assets; $\boldsymbol{A C o m i t}$ is a dichotomous variable coded as 1 for firms with audit committee, 0 otherwise; $\boldsymbol{O C I}$ is the Other Comprehensive Income through income statement; OCInon is the Other Comprehensive Income not through income statement; InvestProp is a dichotomous variable coded as 1 for firms invest in real estate property measured with fair value, 0 otherwise; YearDummy are dummy variable represent date year from 2007 to 2014; IndDummy are dummy variable represent industry categories.

\subsubsection{Three Levels of Input in Fair Valued Assets}

In Model 2, we divide fair valued assets into three categories to examine if the negative association between fair valued assets and audit fees is stronger for Level 2 fair valued assets than that for Level 1 fair valued assets. Dependent variable is the same natural-log-transformed value of audit fees (LnAFee) as in Model 1. Independent variables are the proportion of fair valued asset measured with Level 1, 2, and 3 inputs, FVA1_TA, FVA2_TA, and FVA3_TA, respectively. Model 2 is as follows:

$$
\begin{aligned}
& \text { LnAFee }_{i, t}=\beta_{0}+\beta_{1} \text { FVA1_TA }_{i, t}+\beta_{2} \text { FVA2_TA }_{i, t}+\beta_{3} \text { FVA3_TA }_{i, t}+\beta_{4} \text { LnAsset }_{i, t}+\beta_{5} \text { Big }_{i, t}+\beta_{6} \text { Inv }_{-} \text {TA }_{i, t}+ \\
& \beta_{7} L_{-} T A_{i, t}+\beta_{8} \text { Loss }_{i, t}+\beta_{9} \text { Efficiency }_{i, t}+\beta_{10} \text { IntangA_TA }_{i, t}+\beta_{11} \text { OCF }_{-} \text {II }_{i, t}+\beta_{12} \text { ReState }_{i, t}+ \\
& \beta_{13} \text { LnNAFee }_{i, t}+\beta_{14} \text { ChgCPA }_{i, t}+\beta_{15} \text { ShareP P }_{i, t}+\beta_{16} \text { Opnion }_{i, t}+\beta_{17} \text { ROE }_{i, t}+\beta_{18} \text { Impair }_{i, t}+\beta_{19} \text { AComit }_{i, t}+ \\
& \beta_{20} \text { OCI }_{i, t}+\beta_{21} \text { OCInon }_{i, t}+\beta_{22} \text { InvestProp }_{i, t}+\text { YearDummy }+ \text { IndDummy }
\end{aligned}
$$

Control variables are same as in Model 1.

3.3.3 Interaction of Fair Valued Assets and Audit Committee

In Model 3, we further examine the impact of fair valued assets on audit fees if audit committee is appointed in the 
firm. Kim, Segal, Segal, and Zang (2013) suggest that audit committee members may have more understanding on the consequence of management's opportunisms and failed financial reporting (such as share price decrease or bankruptcy). Beasley, Carcello, Hermanson, and Neal (2009) suggest that investors can have more understanding on the firm by analyzing financial reports under audit committee's monitoring. Loukil (2014) suggests that audit committee members, such as independent directors with finance and accounting profession or frequent attendance members, may help accountants to be more confident with firm's accounting quality and to set lower auditing risk.

In model 3, we add the interaction terms of audit committee and fair valued assets in three levels, FA1_AC, A2_AC, and FA3_AC, as independent variables to examine if adding audit committee in the firm can enhance the impact of fair valued assets on audit fees. Dependent variable is the same natural-log-transformed value of audit fees (LnAFee) as in Model 1 and 2. Model 3 is as follows:

$$
\begin{aligned}
& \text { LnAFee }_{i, t}=\beta_{0}+\beta_{1} F V A 1_{-} T A_{i, t}+\beta_{2} F V A 2_{-} T A_{i, t}+\beta_{3} F V A 3_{-} T A_{i, t}+\beta_{4} \text { LnAsset }_{i, t}+\beta_{5} \text { Big4 }_{i, t}+\beta_{6} \text { Inv }_{-} T A_{i, t}+ \\
& \beta_{7} L_{-} T A_{i, t}+\beta_{8} \text { Loss }_{i, t}+\beta_{9} \text { Efficiency }_{i, t}+\beta_{10} \text { IntangA_T }_{i, t}+\beta_{11} O C F_{-} N I_{i, t}+\beta_{12} \text { ReState }_{i, t}+ \\
& \beta_{13} \text { LnNAFee }_{i, t}+\beta_{14} \text { ChgCPA }_{i, t}+\beta_{15} \text { ShareP }_{i, t}+\beta_{16} \text { Opnion }_{i, t}+\beta_{17} \text { ROE }_{i, t}+\beta_{18} \text { Impair A }_{i, t}+\beta_{19} \text { AComit }_{i, t}+ \\
& \beta_{20} \text { OCI }_{i, t}+\beta_{21} \text { OCInon }_{i, t}+\beta_{22} \text { InvestProp }_{i, t}+\beta_{23} F V A 1_{-} A C_{i, t}+\beta_{24} F V A 2_{-} A C_{i, t}+\beta_{25} F V A 3_{-} A C_{i, t}+ \\
& \text { YearDummy + IndDummy }
\end{aligned}
$$

Control variables are same as in Model 1 and Model 2.

\section{Empirical Analysis}

\subsection{Summary Statistics}

In Table 1, we present summary statistics of variables in three model. The proportion of fair valued assets to total assets (FVA_TA) is $4.63 \%$ on average, with minimum of zero, median of $1.64 \%$, and maximum of $68.53 \%$. Mean value of the proportion of Level 1, Level 2, and Level 3 fair valued assets to total assets (FVA1_TA, FVA2_TA, and FVA3_TA) is $9.41 \%, 0.23 \%$, and $0.19 \%$, respectively. Mean value of Big4 indicates that, on average, $86.19 \%$ of firms in the sample are audited by Big-4 auditors. Mean value of Loss indicates that, on average, $22 \%$ of firms in the sample incurred negative income. Mean value of ReState indicates that, on average, $1.13 \%$ of firms in the sample restate financial reports. Mean value of CngCPA indicates that, on average, 3.48\% of firms in the sample change accounting firms. Mean value of Opinion indicates that, on average, $39.62 \%$ of firms in the sample with Unqualified opinion in audit reports. The average ROE of firms in the sample is $20.41 \%$. On average, $13.61 \%$ of firms in the sample are appointed with audit committee.

\subsection{Empirical Results}

\subsubsection{Fair Value Assets and Audit Fees}

In model 1, we first test if the proportion of fair valued assets in the firm is related to firm's audit fees. Based on results in Table 2, the coefficient of FVA_TA (-0.515) indicates that less audit fees is expected with higher proportion of fair-valued assets. The result supports our Hypothesis 1 and is consistent with Goncharov, Riedl, and Sellhorn's (2014) finding that firm's audit fees will be lower if assets are measured with fair value in financial reports.

In control variables, we find that total asset is positively related to audit fees. Firms audited by Big-4 auditors tend to pay higher audit fees, the finding is consistent with Lee and Park (2013). The ratios of inventory and liability to total assets are both negatively related to audit fees. Higher ratio of intangible assets is related to higher audit fees. The positive association between non-audit fees and audit fees is consistent with the finding of Jubb, Houghton, and Butterworth (1996). The decision of change accounting firm is related to lower audit fees. Audit fees is also positively related to firm's impairment of assets and firm with audit committee.

\subsubsection{Three Levels of Input in Fair Valued Assets}

In model 2, we further divide fair valued assets in model 1 into three input levels and examine their associations with audit fees. In Table 3, we find that the proportion of Level 2 fair valued assets is negatively related to audit fees, a result consistent with Laux and Leuz's (2010) suggestion that firms tend to adopt more Level 2 assets. However, we do not find significant association between Level-1 fair valued assets and audit fees.

In control variables, we find consistent associations between variable and audit fees as found in model 1 such as positive association for total asset and Big 4 auditors and negative association for inventory and liability. Similar positive associations are also found with intangible assets, non-audit fees, impairment of assets, and audit committee. The negative association between change accounting firm and audit fees in Model 2 is less significant than that in 
Model 1.

4.2.3 Interaction of Fair Valued Assets and Audit Committee

In model 3, we add the interaction terms of audit committee and fair valued assets in three levels, FA1_AC, A2_AC, and FA3_AC, to examine if adding audit committee in the firm can enhance the impact of fair valued assets on audit fees. In Table 4, we find negative and significant coefficients for FA1_AC and A2_AC, indicating that the lower audit fees for firms with Level 1 and Level 2 fair valued assets can be further reduced with audit committee added in the firm. The results support Hypothesis 3 and implying that the benefit of information transparency from fair valued assets and monitoring from audit committee may contribute to less burden for auditors and thus lower audit fees.

In control variables, we find consistent associations between variable and audit fees as found in Model 1 and Model 2 such as positive association for total asset and Big 4 auditors and negative association for inventory and liability. Similar positive associations are also found with intangible assets, non-audit fees, impairment of assets, and audit committee. The negative association between change accounting firm and audit fees is similar to that in Model 1 .

Table 1. Summary statistics

\begin{tabular}{llllll}
\hline Variable & Min. & Median & Max. & Mean & Std. Dev. \\
\hline LnAFee & 6.2146 & 8.0064 & 11.1472 & 8.0513 & 0.6043 \\
FVA_TA & 0.0000 & 0.0164 & 0.6853 & 0.0463 & 0.0783 \\
FVA1_TA & 0.0000 & 0.0017 & 121.6004 & 0.0941 & 2.7627 \\
FVA2_TA & 0.0000 & 0.0000 & 0.3424 & 0.0023 & 0.0160 \\
FVA3_TA & 0.0000 & 0.0000 & 0.1720 & 0.0019 & 0.0107 \\
LnAsset & 10.7044 & 15.3456 & 21.1254 & 15.5853 & 1.5191 \\
Big4 & 0.0000 & 1.0000 & 1.0000 & 0.8619 & 0.3451 \\
Inv_TA & 0.0000 & 0.1200 & 0.9588 & 0.1557 & 0.1527 \\
Liability & 0.0048 & 0.5711 & 209.9396 & 1.1679 & 6.5675 \\
Loss & 0.0000 & 0.0000 & 1.0000 & 0.2204 & 0.4146 \\
Efficiency & 0.0105 & 0.1314 & 214.3137 & 0.4282 & 5.4000 \\
IntangA_TA & 0.0000 & 0.0013 & 0.4342 & 0.0099 & 0.0339 \\
OCF_NI & -22.5078 & 1.1310 & 44.1174 & 1.7690 & 6.8442 \\
ReState & 0.0000 & 0.0000 & 1.0000 & 0.0113 & 0.1056 \\
LnNAFee & 0.0000 & 5.6768 & 10.0031 & 4.9536 & 2.4990 \\
ChgCPA & 0.0000 & 0.0000 & 1.0000 & 0.0348 & 0.1832 \\
ShareP & 1.0000 & 22.0000 & 2353.7300 & 36.8231 & 72.6098 \\
Opinion & 0.0000 & 0.0000 & 1.0000 & 0.3962 & 0.4892 \\
ROE & -78.0000 & 10.0000 & 434.0000 & 20.4104 & 46.6696 \\
ImpairA & 0.0000 & 0.0000 & 1.0000 & 0.2145 & 0.4106 \\
AComit & 0.0000 & 0.0000 & 1.0000 & 0.1361 & 0.3430 \\
OCI & -0.1344 & 0.0017 & 0.4091 & 0.0049 & 0.0192 \\
OCInon & -0.1023 & 0.0016 & 0.5273 & 0.0046 & 0.0237 \\
InvestProp & 0.0000 & 0.0000 & 1.0000 & 0.3683 & 0.4825 \\
FVA1_AC & 0.0000 & 0.0000 & 0.4281 & 0.0034 & 0.0245 \\
FVA2_AC & 0.0000 & 0.0000 & 0.3110 & 0.0005 & 0.0096 \\
FVA3_AC & 0.0000 & 0.0000 & 0.1720 & 0.0003 & 0.0055 \\
\hline Des & & & & \\
\hline
\end{tabular}

Description: Sample size: 2,042 observations; LnAFee is the natural-log-transformed value of audit fees; FVA_TA is the proportion of fair valued assets; FVA1_TA is fair-valued asset using Level 1 inputs and deflated by total assets; 
FVA2_TA is fair-valued asset using Level 2 inputs and deflated by total assets; FVA3_TA is fair-valued asset using Level 3 inputs and deflated by total assets; LnAsset is the natural-log-transformed of total assets; Big4 is a dichotomous variable coded as 1 for firms audited by Big- 4 auditors and 0 for non-Big- 4 auditors; Inv_TA is inventory and deflated by total assets; $\mathbf{L}_{-} \mathbf{T A}$ is liability and deflated by total assets; Loss is a dichotomous variable coded as 1 for firms with negative net income, 0 otherwise; Efficiency is measured by dividing operating expenses by total revenue; IntangA_TA is intangible assets and deflated by total assets; OCF_NI is operating cashflows and deflated by net income; ReState is a dichotomous variable coded as 1 for accounting restatement, 0 otherwise; LnNAFee is the natural-log-transformed value of non-audit fees; CngCPA is a dichotomous variable coded as 1 for firms change accounting firms, 0 otherwise; ShareP is the share price of firm; Opinion is a dichotomous variable coded as 1 for firms with Unqualified opinion in audit report, 0 otherwise; ROE is return on equity; ImpairA is the natural-log-transformed value of impairment of assets; AComit is a dichotomous variable coded as 1 for firms with audit committee, 0 otherwise; OCI is the Other Comprehensive Income through income statement; OCInon is the Other Comprehensive Income not through income statement; InvestProp is a dichotomous variable coded as 1 for firms invest in real estate property measured with fair value, 0 otherwise; FVA1_AC is the interaction terms of Level 1 fair-valued assets and audit committee; FVA2_AC is the interaction terms of Level 2 fair-valued assets and audit committee; FVA3_AC is the interaction terms of Level 3 fair-valued assets and audit committee.

Table 2. Regression Results of Fair Value Assets and Audit Fees (Model 1)

\begin{tabular}{llll}
\hline Variable & Coefficient & t-value & p-value \\
\hline Constant & 3.6419 & 18.8480 & 0.0000 \\
FVA_TA & -0.5147 & -4.4137 & 0.0000 \\
LnAsset & 0.2597 & 35.4828 & 0.0000 \\
Big4 & 0.2036 & 7.4916 & 0.0000 \\
Inv_TA & -0.2006 & -2.5267 & 0.0116 \\
Liability & -0.0069 & -5.0496 & 0.0000 \\
Loss & 0.0228 & 0.9873 & 0.3236 \\
Efficiency & -0.0002 & -0.1492 & 0.8814 \\
IntangA_TA & 1.1043 & 4.1180 & 0.0000 \\
OCF_NI & -0.0012 & -0.9386 & 0.3480 \\
ReState & 0.0818 & 0.9742 & 0.3301 \\
LnNAFee & 0.0258 & 7.0177 & 0.0000 \\
ChgCPA & -0.1074 & -2.1789 & 0.0295 \\
ShareP & -0.0005 & -3.6934 & 0.0002 \\
Opinion & 0.0256 & 1.3763 & 0.1689 \\
ROE & 0.0003 & 1.7474 & 0.0807 \\
ImpairA & 0.0731 & 3.2067 & 0.0014 \\
AComit & 0.1051 & 3.9505 & 0.0001 \\
OCI & 1.3727 & 1.7152 & 0.0865 \\
OCInon & 0.0313 & 0.0489 & 0.9610 \\
InvestProp & -0.0368 & -1.8716 & 0.0614 \\
\hline Desciptis & 0.969 &
\end{tabular}

Description: Sample size: 2,042 observations; dependent variable LnAFee is the natural-log-transformed value of audit fees; FVA_TA is the proportion of fair valued assets; LnAsset is the natural-log-transformed of total assets; Big4 is a dichotomous variable coded as 1 for firms audited by Big-4 auditors and 0 for non-Big-4 auditors; Inv_TA is inventory and deflated by total assets; $\mathbf{L} \_\mathbf{T A}$ is liability and deflated by total assets; Loss is a dichotomous variable coded as 1 for firms with negative net income, 0 otherwise; Efficiency is measured by dividing operating 
expenses by total revenue; IntangA_TA is intangible assets and deflated by total assets; OCF_NI is operating cashflows and deflated by net income; ReState is a dichotomous variable coded as 1 for accounting restatement, 0 otherwise; LnNAFee is the natural-log-transformed value of non-audit fees; CngCPA is a dichotomous variable coded as 1 for firms change accounting firms, 0 otherwise; ShareP is the share price of firm; Opinion is a dichotomous variable coded as 1 for firms with Unqualified opinion in audit report, 0 otherwise; ROE is return on equity; ImpairA is the natural-log-transformed value of impairment of assets; AComit is a dichotomous variable coded as 1 for firms with audit committee, 0 otherwise; OCI is the Other Comprehensive Income through income statement; OCInon is the Other Comprehensive Income not through income statement; InvestProp is a dichotomous variable coded as 1 for firms invest in real estate property measured with fair value, 0 otherwise.

Table 3. Regression Results of Three Levels Fair Valued Assets and Audit Fees (Model 2)

\begin{tabular}{|c|c|c|c|}
\hline Variable & Coefficient & t-value & $\mathrm{p}$-value \\
\hline Constant & 3.6060 & 18.6332 & 0.0000 \\
\hline FVA1_TA & -0.0044 & -1.4138 & 0.1576 \\
\hline FVA2_TA & -1.5373 & -2.8198 & 0.0049 \\
\hline FVA3_TA & -0.0788 & -0.0964 & 0.9232 \\
\hline LnAsset & 0.2599 & 35.3412 & 0.0000 \\
\hline Big4 & 0.2127 & 7.7990 & 0.0000 \\
\hline IntangA_TA & -0.1421 & -1.8107 & 0.0703 \\
\hline Liability & -0.0069 & -5.0555 & 0.0000 \\
\hline Loss & 0.0291 & 1.2572 & 0.2088 \\
\hline Efficiency & -0.0008 & -0.4893 & 0.6246 \\
\hline IntangA_TA & 1.1669 & 4.3453 & 0.0000 \\
\hline OCF_NI & -0.0010 & -0.7571 & 0.4491 \\
\hline ReState & 0.0980 & 1.1630 & 0.2450 \\
\hline LnNAFee & 0.0262 & 7.0962 & 0.0000 \\
\hline ChgCPA & -0.0953 & -1.9297 & 0.0538 \\
\hline ShareP & -0.0005 & -3.7138 & 0.0002 \\
\hline Opinion & 0.0184 & 0.9900 & 0.3223 \\
\hline ROE & 0.0004 & 1.8860 & 0.0594 \\
\hline ImpairA & 0.0770 & 3.3587 & 0.0008 \\
\hline AComit & 0.1088 & 4.0726 & 0.0000 \\
\hline OCI & 1.1213 & 1.4025 & 0.1609 \\
\hline OCInon & 0.1023 & 0.1593 & 0.8734 \\
\hline InvestProp & -0.0377 & -1.9112 & 0.0561 \\
\hline
\end{tabular}

Description: Sample size: 2,042 observations; dependent variable LnAFee is the natural-log-transformed value of audit fees; FVA1_TA is fair-valued asset using Level 1 inputs and deflated by total assets; FVA2_TA is fair-valued asset using Level 2 inputs and deflated by total assets; FVA3_TA is fair-valued asset using Level 3 inputs and deflated by total assets; LnAsset is the natural-log-transformed of total assets; Big4 is a dichotomous variable coded as 1 for firms audited by Big-4 auditors and 0 for non-Big-4 auditors; Inv_TA is inventory and deflated by total assets; L_TA is liability and deflated by total assets; Loss is a dichotomous variable coded as 1 for firms with negative net income, 0 otherwise; Efficiency is measured by dividing operating expenses by total revenue; IntangA_TA is intangible assets and deflated by total assets; $\mathbf{O C F}$ _NI is operating cashflows and deflated by net income; ReState is a dichotomous variable coded as 1 for accounting restatement, 0 otherwise; LnNAFee is the 
natural-log-transformed value of non-audit fees; CngCPA is a dichotomous variable coded as 1 for firms change accounting firms, 0 otherwise; ShareP is the share price of firm; Opinion is a dichotomous variable coded as 1 for firms with Unqualified opinion in audit report, 0 otherwise; ROE is return on equity; ImpairA is the natural-log-transformed value of impairment of assets; AComit is a dichotomous variable coded as 1 for firms with audit committee, 0 otherwise; OCI is the Other Comprehensive Income through income statement; OCInon is the Other Comprehensive Income not through income statement; InvestProp is a dichotomous variable coded as 1 for firms invest in real estate property measured with fair value, 0 otherwise.

Table 4. Regression Results of Interaction of Fair Valued Assets and Audit Committee (Model 3)

\begin{tabular}{|c|c|c|c|}
\hline Variable & Coefficient & $\mathrm{t}$-value & p-value \\
\hline Constant & 3.6255 & 18.7717 & 0.0000 \\
\hline FVA1_TA & -0.0043 & -1.3884 & 0.1652 \\
\hline FVA2_TA & -0.2864 & -0.4273 & 0.6692 \\
\hline FVA3_TA & 0.3477 & 0.3669 & 0.7138 \\
\hline LnAsset & 0.2580 & 35.0469 & 0.0000 \\
\hline Big4 & 0.2105 & 7.7337 & 0.0000 \\
\hline Inv_TA & -0.1577 & -2.0112 & 0.0444 \\
\hline Liability & -0.0069 & -5.0430 & 0.0000 \\
\hline Loss & 0.0288 & 1.2461 & 0.2129 \\
\hline Efficiency & -0.0002 & -0.1113 & 0.9114 \\
\hline IntangA_TA & 1.1347 & 4.2346 & 0.0000 \\
\hline OCF_NI & -0.0010 & -0.7720 & 0.4402 \\
\hline ReState & 0.0803 & 0.9536 & 0.3404 \\
\hline LnNAFee & 0.0267 & 7.2421 & 0.0000 \\
\hline ChgCPA & -0.1088 & -2.2037 & 0.0277 \\
\hline ShareP & -0.0005 & -3.7081 & 0.0002 \\
\hline Opinion & 0.0244 & 1.3138 & 0.1891 \\
\hline ROE & 0.0004 & 2.0023 & 0.0454 \\
\hline ImpairA & 0.0796 & 3.4766 & 0.0005 \\
\hline AComit & 0.1417 & 4.9037 & 0.0000 \\
\hline OCI & 1.1669 & 1.4620 & 0.1439 \\
\hline OCInon & 0.1123 & 0.1754 & 0.8607 \\
\hline InvestProp & -0.0378 & -1.9256 & 0.0543 \\
\hline FVA1_AC & -0.7351 & -1.7775 & 0.0756 \\
\hline FVA2_AC & -2.9853 & -2.4909 & 0.0128 \\
\hline FVA3_AC & -1.7789 & -0.9639 & 0.3352 \\
\hline
\end{tabular}

Description: Sample size: 2,042 observations; dependent variable LnAFee is the natural-log-transformed value of audit fees; FVA1_TA is fair-valued asset using Level 1 inputs and deflated by total assets; FVA2_TA is fair-valued asset using Level 2 inputs and deflated by total assets; FVA3_TA is fair-valued asset using Level 3 inputs and deflated by total assets; LnAsset is the natural-log-transformed of total assets; Big4 is a dichotomous variable coded as 1 for firms audited by Big-4 auditors and 0 for non-Big-4 auditors; Inv_TA is inventory and deflated by total assets; L_TA is liability and deflated by total assets; Loss is a dichotomous variable coded as 1 for firms with negative net income, 0 otherwise; Efficiency is measured by dividing operating expenses by total revenue; IntangA_TA is intangible assets and deflated by total assets; $\mathbf{O C F}$ _NI is operating cashflows and deflated by net income; ReState is a dichotomous variable coded as 1 for accounting restatement, 0 otherwise; LnNAFee is the natural-log-transformed value of non-audit fees; CngCPA is a dichotomous variable coded as 1 for firms change accounting firms, 0 otherwise; ShareP is the share price of firm; Opinion is a dichotomous variable coded as 1 for 
firms with Unqualified opinion in audit report, 0 otherwise; ROE is return on equity; ImpairA is the natural-log-transformed value of impairment of assets; AComit is a dichotomous variable coded as 1 for firms with audit committee, 0 otherwise; OCI is the Other Comprehensive Income through income statement; OCInon is the Other Comprehensive Income not through income statement; InvestProp is a dichotomous variable coded as 1 for firms invest in real estate property measured with fair value, 0 otherwise; FVA1_AC is the interaction terms of Level 1 fair-valued assets and audit committee; FVA2_AC is the interaction terms of Level 2 fair-valued assets and audit committee; FVA3_AC is the interaction terms of Level 3 fair-valued assets and audit committee.

\section{Conclusion}

In this study, we explore the association between audit fees and proportion of fair valued assets for publicly listed firms in Taiwan between 2007 and 2014. We further examine the association when audit committee is added in the firms. The results indicate lower audit fees is related to higher proportion of fair valued assets, a finding which is consistent to Goncharov, Riedl, and Sellhorn's (2014) proposition that firms pay lower audit fees with fair value model than with cost model. We also find negative association between audit fees and the proportion of Level 2 fair valued assets. The association is not significant for Level 3 fair valued assets, a result similar to Glover, Taylor, and Wu's (2014) suggestion that firm's reluctant attitude in adopting Level 3 assets due to less reliable information or investor's suspicion. Last of all, we find that when audit committee is appointed, firm's audit fees is negatively associated with Level 1 and Level 2 fair valued assets, implying audit committee's role in monitoring firm's fair valued assets and further reducing auditing risk and audit fees.

To our knowledge, our finding contributes to current research on corporate governance and fair value assets in Taiwan, especially the global convergence of U.S. featured audit committee (Dallas and Scott, 2006; Hsu, 2014) in Taiwanese firms for monitoring purpose. However, given the impact of financial crisis on data, it is worthwhile in future studies to differentiate sample period into within crisis (before 2009) and post crisis (after 2009) period for further refinements.

\section{References}

Beasley, M. S., J. V. Carcello, D. R. Hermanson, \& T. L. Neal. (2009). The Audit Committee Oversight Process. Contemporary Accounting Research, 26, 65-122. http://dx.doi.org/10.1506/car.26.1.3

Cahan, S., D. Emanuel, D. Hay, \& N. Wong. (2008). Non-audit fees, long-term auditor-client relationships and earnings management. Accounting \& Finance, $48, \quad 207$. http://dx.doi.org/10.1111/j.1467-629X.2008.00251.x

Casey, R. J., \& J. H. Grenier. (2015, February). Understanding and Contributing to the Enigma of Corporate Social Responsibility (CSR) Assurance in the United States. Auditing: A Journal of Practice \& Theory, 34(1), 97-130. http://dx.doi.org/10.2308/ajpt-50736

Dallas, G., \& Scott, H. (2006). Can one set of results fit all? Mandatory corporate behavior. Corporate Governance Law Review, 2(2), 117-144.

Davis, L., D. Ricchiute, \& G. Trompeter. (1993). Audit Effort, Audit Fees, and the Provision of Non-Audit Services to Audit Clients. The Accounting Review, 68, 135-150.

Duh, R., W. Lee, C. Lin, \& J. Chu. (2007). An Experimental Study on Non-audit Service and Auditor Decisions: Pre and Post-Pro comp Scandal. Taiwan Accounting Review, 6, 125-152.

Earley, C. E., V. B. Hoffman, \& J. R. Joe. (2014). Auditors' Role in Level 2 versus Level 3 Fair-Value Classification Judgments (December 17, 2014). http://dx.doi.org/10.2139/ssrn.2119720

Ettredge, M. L., Y. Xu, \& H. S. Yi. (2014, August). Fair Value Measurements and Audit Fees: Evidence from the Banking Industry. Auditing: A Journal of Practice \& Theory, 33(3), 33-58.

Francis, J. R., \& M. D. Yu. (2009, September). Big 4 Office Size and Audit Quality. The Accounting Review, 84(5), 1521-1552.

Glover, S. M., M. Taylor, \& Y. Wu. (2014). Closing the Gap between Auditor Performance and Regulators' Expectations when Auditing Fair Value Measurements: Evidence from Practicing Audit Partners. Working Paper, Brigham Young University.

Goncharov, I., E. J. Riedl, \& T. Sellhorn. (2014). Fair value and audit fees. Rev Account Stud., 19 , 210. http://dx.doi.org/10.1007/s11142-013-9248-5 
Gul, F. A., \& J. S. L. Tsui. (2001). Free Cash Flow, Debt Monitoring, and Audit Pricing: Further Evidence on the Role of Director Equity Ownership. Auditing: A Journal of Practice \& Thoery, 20, 71-84.

Hsu, A. W. H. (2014). Can audit committee improve earnings quality more than the supervisors in Taiwan? NTU Management Review, 24, 203-232. http://dx.doi.org/10.6226/NTURM2014.JUN.R11002

Jubb, C.A., K.A. Houghton, \& S. Butterworth. (1996). Audit fee determinants: the plural nature of risk. Managerial Auditing Journal, 11(3), 25-40. http://dx.doi.org/10.1108/02686909610115222

Kim, J. B., B. Segal, D. Segal, \& Y. Zang. (2013). The Triangular Relationship Between Audit Committee Characteristics. Audit Input and Financial Reporting Quality. Research Collection School of Accountancy (SMU Access Only). Retrieved from http://ink.library.smu.edu.sg/soa_research_smu/16

Laux, C., \& C. Leuz. (2010). Did Fair-Value Accounting Contribute to the Financial Crisis?. The Journal of Economic Perspectives, 24(1), Winter, (26), 93-118.

Lee, C., \& M. S. Park. (2013). Subjectivity in fair-value estimates, audit quality, and informativeness of other comprehensive income. Advances in Accounting, 29(2), 218-231

Loukil, L. (2014, Oct.). Audit Committees and Audit Fees: An Empirical Study in Large French Listed Companies. Journal of Accounting, Business \& Management, 21(2), 18, 36-53.

Palmrose, Z-V. (1986). The Effect of Nonaudit Services on the Pricing of Audit Services: Further Evidence. Journal of Accounting Research, 24(2), Autumn, 405-411.

Ramanna, K., \& R. L. Watts. (2009). Evidence from goodwill non-impairments on the effects of using unverifiable estimates in financial reporting. Working paper.

Simon, D. A. (1985). The Audit Service Market: Additional Empirical Evidence. Journal of Practice and Theory, 5, 71-78.

Simon, D. T., \& J. R. Francis. (1988, Apr.). The Effects of Auditor Change on Audit Fees: Tests of Price Cutting and Price Recovery. The Accounting Review, 63(2), 255-269

Simunic, D. A. (1980). The pricing of audit services: theory and evidence. Journal of Accounting Research, 18(1), Spring,161-190.

Simunic, D. A. (1984). Auditing, Consulting, and Auditor Independence. Journal of Accounting Research, 22(2), Autumn, 679-702

Sirois, L-P., \& D. A. Simunic. (2011). Auditor Size and Audit Quality Revisited: The Importance of Audit Technology (July 1, 2011). http://dx.doi.org/10.2139/ssrn.1694613

Song, C. J., W. B. Thomas, \& H. Yi. (2010, July). Value Relevance of FAS No. 157 Fair Value Hierarchy Information and the Impact of Corporate Governance Mechanisms. The Accounting Review, 85(4), 1375-1410. http://dx.doi.org/10.2308/accr.2010.85.4.1375

Su, Y. (2000). Audit fees and auditor size a study of audit market in Taiwan. Taiwan Accounting Research, 59-78.

Whisenant, J. S., S. Sankaraguruswamy, \& K. Raghunandan. (2003, March). Market Reactions to Disclosure of Reportable Events. Auditing: A Journal of Practice \& Theory, 22(1), 181-194. 